\title{
Effects of human chorionic gonadotropin on the normal testicular tissue of rats ${ }^{1}$
}

\author{
Patricia Magnago AltoéI, Edson Samesima Tatsuo ${ }^{I I}$, Danilo Nagib Salomão Paulo ${ }^{\mathrm{III}}$, Robson Jarske ${ }^{\mathrm{IV}}$, Marcel Milagres ${ }^{\mathrm{V}}$, Igor \\ Daniel Loureirov
}

DOI: http://dx.doi.org/10.1590/S0102-86502014000500002

IMaster, Surgery Department, Minas Gerais Federal University (UFMG), Minas Gerais, Brazil. Conception, design and scientific content of the study; manuscript writing.

"Full Professor, Surgery Department, UFMG, Minas Gerais, Brazil. Conception, design and scientific content of the study.

IIIFull Professor, Surgery Department, Santa Casa de Misericordia de Vitoria (EMESCAM), Vitoria-ES, Brazil. Surgical procedures, critical revision.

${ }^{\mathrm{IV}}$ Master, Pathology Department, Espirito Santo Federal University (UFES), Brazil. Histopathologic examinations, critical revision.

${ }^{v}$ Graduate student, Vila Velha University (UVV), Brazil. Histopathologic examinations.

\section{ABSTRACT}

PURPOSE: To investigate the effects of human chorionic gonadotropin (hCG) on the testicular tissue of young male rats.

METHODS: Male Wistar rats were assigned to groups (10 rats/group).Control Group received subcutaneous saline solution; Group 1 received hCG 50UI/Kg/dose; and Group 2 received hCG $100 \mathrm{UI} / \mathrm{Kg} / \mathrm{dose}$, daily for 15 days. Half was submitted to bilateral orchiectomy on the $16^{\text {th }}$ day and the other half 45 days after the beginning of the hormone application. Testicles were weighed, measured and has their volumes determined. The diameter of the tubules and the thickness of the seminiferous epithelium were measured.

RESULTS: Control Group presented the highest values of testicles volume and weight. Rats in the Control presented normal histology. In G1 and G2 atrophy of the seminiferous tubules, apoptosis of germ cells and multinucleated giant cells were observed. Comparing groups, in the first operation Control rats had higher diameter values. In the second operation, the Control was only different from G1. As for thickness, Control had higher values in both operations. Comparing the time of operation, the diameter values were higher in G1 and $\mathrm{G} 2$ in the second operation. For all groups, the thickness of the epithelium was higher in the second operation.

CONCLUSIONS: Human chorionic gonadotropin is gonadotoxic in rats. This effect was temporary and can affect reproductive potential. The total recovery of testicular damage in the studied range could not be proved, and the effects were not dose-dependent.

Key words: Chorionic gonadotropin. Receptors, LH. Testis. Animal experimentation. Rats. 


\section{Introduction}

Cryptorchidism is characterized by the incomplete embryological migration of testicles through its normal descent path to the scrotum. It is one of the most common congenital anomalies in males. It affects approximately one-third of premature infants and $3-4 \%$ of full-term live births, whose prevalence decreases to $0.8 \%$ at one year of age. It is an important risk factor for testicle tumor and an important cause of infertility. More than half of unilateral cases and $75 \%$ of bilateral cases are associated with any fertility problems. Efforts to improve the rates of fertility are directed towards early surgical intervention and, more recently, hormonal therapy ${ }^{1}$.

Hormonal therapy was introduced in 1930 and the first hormone to be used was the human chorionic gonadotropin (hCG $)^{2-}$ ${ }^{4}$. Hormonal therapy is used to induce the descent of the testicles and/or to locate impalpable testicles. The use of hCG stimulates the Leydig cells of testicles to produce testosterone. The gonadotropinreleasing hormone $(\mathrm{GnRH})$ stimulates the pituitary gland to secrete LH which, in its turn, stimulates the Leydig cells to produce testosterone and start the descent of the testicles ${ }^{1,5}$. Currently, hormonal therapy is also used to stimulate the proliferation and maturation of germ cells, contributing to improve fertility ${ }^{5}$.

The results of hormone therapy vary greatly and depend on many factors, among those: doses, treatment intervals and age of the boys studied ${ }^{2,5}$. Success rates concerning testicular descent vary from $10 \%$ to $99 \%$, and the majority of cases reach about $20 \%$ of success ${ }^{3,5,6}$. The most commonly used hormone for treating undescended testis is the hCG, exclusively or in association with other hormones (LHRH/GnRH).

There is still controversy concerning the safety and efficacy of hormonal therapy. Several studies justify its use, before and/or after surgery or even as monotherapy, with beneficial effects on fertility rates (increase in number and maturation of spermatogonia) $)^{1,7-10}$. Other studies, however, show deleterious effects after the use of hormones, with changes in the histology of cryptic or contralateral testicles, such as an increase in the apoptosis rate and smaller number of germ cells ${ }^{3,8,12}$. Or, also, with degeneration and hypocellularity of the germinal epithelium, margination of chromatin organization of round spermatids and formation of multinucleated giant cells ${ }^{13,14}$. There are, still, doubts involving the long-term effects of hCG on the testicles ${ }^{12}$.

The adverse effect of hCG on germinal cells would be probably due to the effect of androgens withdrawal. The administration of hCG (acute and in high doses) stimulates the production of androgens by the Leydig cells, which is normally absent in pre-pubescent testicles. Later, with the suspension of the hCG injections and consequently no further stimulus to the Leydig cells, the production of androgens stops and results in a sudden drop in androgens levels, which was previously proved to results

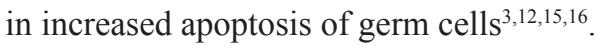

Some experimental studies in rats have shown few benefits in the hormonal treatment of cryptorchidism and even deleterious effects ${ }^{17,18}$.

Human testicle is an organ susceptible to toxic environmental or therapeutic agents that compromise spermatogenesis through different mechanisms, such as changes in spermiogenesis, induction of apoptosis in germ cells, azoospermia and even infertility. In the assessment of possible toxic effects of different substances or of dysfunctions in spermatogenesis, the histopathological analysis of the testicle is considered one of most traditional strategies to analyze morphological (qualitative aspect of seminiferous epithelium) and morphometric parameters (quantitative aspect of seminiferous epithelium) of seminiferous tubules in pathological conditions or different treatments in comparison with normal individuals ${ }^{19}$.

This study uses an experimental model, in rats, to study testicular histology, as testicular development is similar in rats and humans. Rats proved to be a reliable model in several studies, and can be used in studies which purpose is to decode cellular, molecular and biochemical events that occur in the testicles.

This study aims to investigate the effects of human chorionic gonadotropin (hCG) in the testicular tissue of normal immature young male rats, without cryptorchidism, through the histological assessment of the testicles.

\section{Methods}

This study was approved by the Ethics Committee for Animal Studies, UFMG (protocol $n^{\circ}$ 297/2012) and by the Ethics Committee for Animal Studies of the College of Sciences of the Holy House of Mercy, EMESCAM (protocol nº 005/2012).

Thirty male Wistar rats aged 30 to 45 days were used, provided by the EMESCAM vivarium. The rats were divided into three groups of ten rats each, randomly. Control Group received saline solution subcutaneously (SC) for 15 days; Group 1 received a daily dose of hCG (Chorulon $\left.{ }^{\circledR} 5000 \mathrm{IU}\right)$ as $50 \mathrm{UI} / \mathrm{Kg} /$ dose SC for 15 days; and Group 2 received a daily dose of hCG as $100 \mathrm{UI} / \mathrm{Kg} /$ dose SC for 15 days. Half the animals in each group (five animals) were submitted to bilateral orchiectomy under anesthesia, and were euthanized (by intraperitoneal pentobarbital overdose and intracardiac potassium chloride) on the $16^{\text {th }}$ day after 
the initial application of hormone. The other half was euthanized 45 days after the initial application of hormone.

The animals were kept in cages with up to four animals, separated according to each group, and kept at room temperature with controlled lighting. They were given ad libitum water and food adequate for the species. They were weighed at the start of the project, after 15 days of hormone applications and on the day of surgery.

After being anesthetized with sodium pentobarbital 3\% (Hypnol 3\%) at a $60 \mathrm{mg} / \mathrm{Kg}$ dose, the testicles were collected, separated from the epididymidis, measured with the aid of a pachymeter (length, width and thickness) and weighed on a precision digital scale (Adventure OHAUS scale, model AR 3130). Subsequently, the testes were fixed in $10 \%$ buffered formalin for later histological evaluation. The animals were euthanized with pentobarbital sodium 3\% at a dose of $150 \mathrm{mg} /$ $\mathrm{Kg}$ and intracardiac potassium chloride $(100 \mathrm{mg} / \mathrm{Kg})$.

The testicular fragments obtained in the extremities and center areas were used for the preparation of slides for histology. They were fixed in formalin 10\%. Afterwards, dehydrated in ascending alcohol series, diaphonized in xylol and included in paraffin. $5 \mu \mathrm{m}$ sections were obtained. The sections were stained with hematoxylin and eosin (HE) as per the usual techniques of the Laboratory of Morphology of the Department of Pathology of the Espirito Santo University Hospital - Cassiano Antônio de Moraes - HUCAM (UFES) and examined in optical microscope (Olympus BX-50).

The quantitative histological analyses were conducted as follows. For the estimation of the Diameter of seminiferous tubules (DST), 30 transverse sections of tubules were measured, in each testicle, chosen randomly and with the roundest possible contour, in a total 60 tubules/animal. For that, the measurements were made by optical microscopy, using an Olympus x10 micrometer eyepiece coupled with a $\mathrm{x} 4$ object glass. The software Images Plus 2.0 ML was used for the analysis of images. Two diametrically opposite measurements were made, and the average between them was calculated (Figure 1).
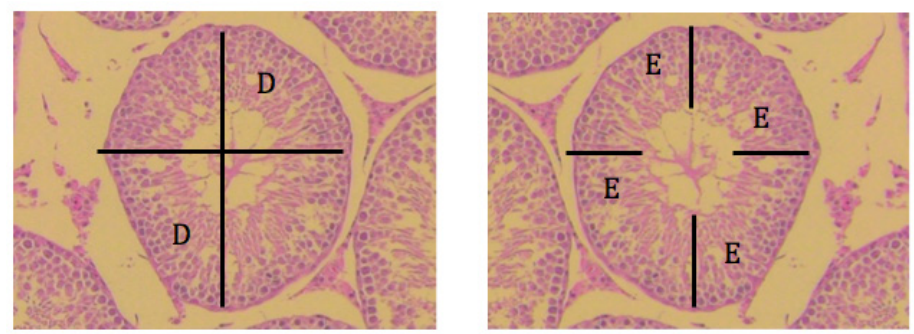

FIGURE 1 - Seminiferous tubule. D: diameter of the seminiferous tubule. E: thickness of the seminiferous epithelium (x100, H\&E stain).
The same sections used to measure the diameter of the seminiferous tubules were used for the measurement of the thickness of the seminiferous epithelium (TSE), which was taken from the proper tunic until the tubular lumen. The value found for the thickness of the seminiferous epithelium in each tubule represented the average of four measurements taken in the four quadrants of the tubule $\left(90^{\circ}, 180^{\circ}, 270^{\circ}\right.$ and $\left.360^{\circ}\right)$ (Figure 1).

\section{Results}

All rats were treated with $\mathrm{hCG}$, but two groups received different doses. The testicles were evaluated at two different moments to study the possible histological effects of the hormone and its relation with the dose and surgery timing. The groups were compared against each other and with a control group. The results are presented as median, mean and standard deviation.

No statistically significant differences were found between groups in both operations, tor the variable Initial Weight of the rat.

The Weight of the testicles ranged between $0,559 \mathrm{~g}$ and $2.02 \mathrm{~g}$. Statistically significant difference was found between the groups in both operations, and the Control group showed the highest values.

Testicular Volume ranged from $0.5 \mathrm{~cm}^{3}$ to $1.72 \mathrm{~cm}^{3}$. Statistically significant differences were found between the groups in two operations. The Control group presented higher volume values.

All the rats in the Control Group, regardless of the time of the surgery, presented normal testicular histology: seminiferous tubules with appropriate sizes and seminiferous epithelium full of germ cells, with preserved architecture. However, in Groups 1 and 2 , in some animals, it was observed atrophy of the seminiferous tubules with degeneration of germ cells and decrease in their number (apoptosis). Loss of the architecture of the epithelium with desquamation of germ cells in the lumen was also observed, as well as the abnormal presence of multinucleated giant cells in the epithelium and vacuolization of Sertoli cells. These changes were observed in the majority of rats in the first surgery, both in Group 1 and 2, and in a few rats in the second surgery, in Group 1 (Figures 2 and 3).

The diameter of the seminiferous tubules and the thickness of the seminiferous epithelium were measured. 

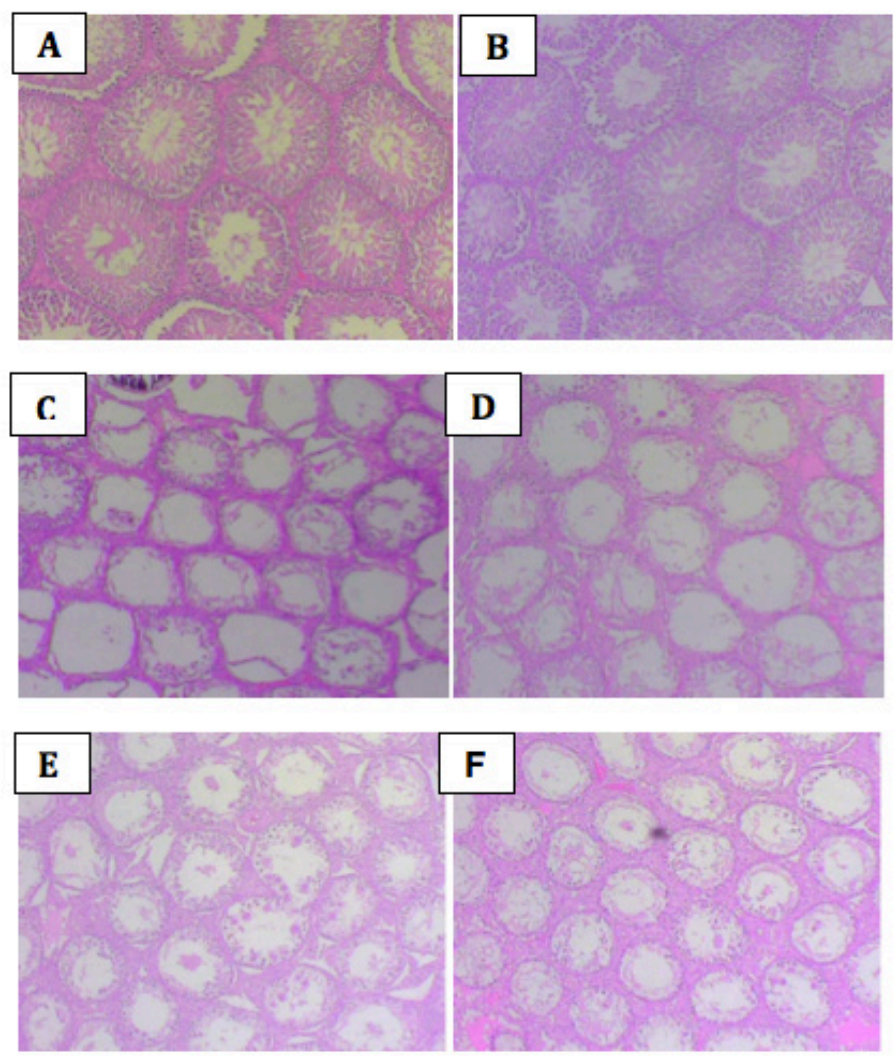

FIGURE 2 - Testicular tissue. Control group (A and B). Group 1 (C and D). Group 2 (E and F) (x40, H\&E stain).

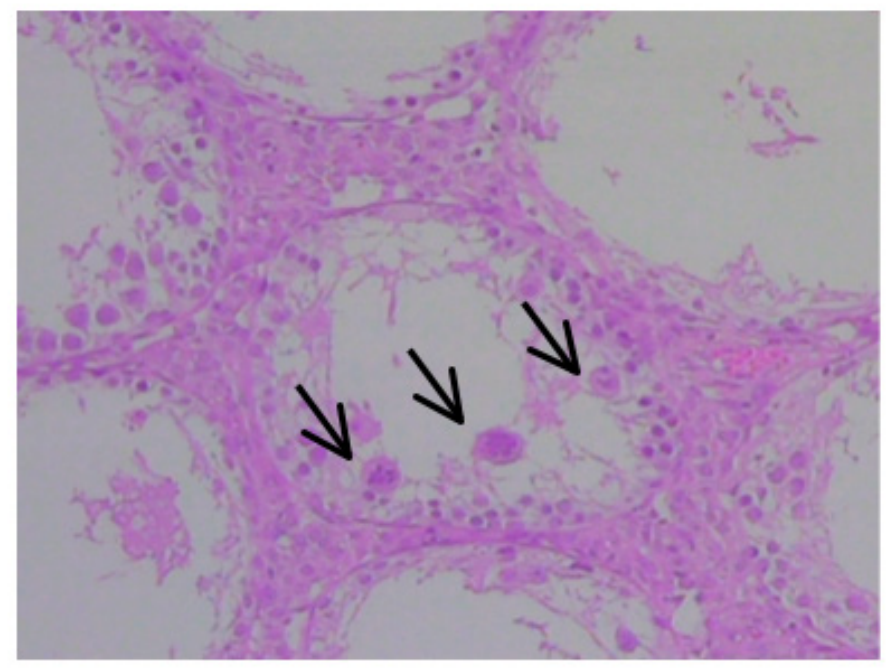

FIGURE 3 - Seminiferous tubule. Presence of multinucleated giant cells (arrows). Group 1 (G1) (x100, H\&E stain).

Diameter in the Control group ranged from $151.25 \mu \mathrm{m}$ to $398.95 \mu \mathrm{m}$ in the first surgery and from $161.50 \mu \mathrm{m}$ to $382.40 \mu \mathrm{m}$ in the second. In Group 1, from $106.1 \mu \mathrm{m}$ to $366.6 \mu \mathrm{m}$ in the first and from $114.2 \mu \mathrm{m}$ to $410.45 \mu \mathrm{m}$ in the second surgery. And in group 2, from $140.5 \mu \mathrm{m}$ to $323.15 \mu \mathrm{m}$ in the first and from $146.45 \mu \mathrm{m}$ to $391.35 \mu \mathrm{m}$ in the second surgery.
The thickness of the epithelium in the Control group ranged from $32.8 \mu \mathrm{m}$ to $117.1 \mu \mathrm{m}$ in the first operation and from $37.3 \mu \mathrm{m}$ to $120 \mu \mathrm{m}$ in the second. In Group 1, from $11.8 \mu \mathrm{m}$ to $95.2 \mu \mathrm{m}$ in the first and from $11.2 \mu \mathrm{m}$ to $118.2 \mu \mathrm{m}$ in the second surgery. And in group 2, from $12.3 \mu \mathrm{m}$ to $93.4 \mu \mathrm{m}$ in the first and from $34 \mu \mathrm{m}$ to $121.5 \mu \mathrm{m}$ in the second surgery.

Statistically significant difference was observed between the groups in both operations, and in the first operation the Control group had higher diameter values than G1 and G2, which were similar between themselves; in the second operation the Control group was different from and had higher values only when compared to G1. G2 had no difference from Control or from G1, as shown in Table 1.

TABLE 1 - Descriptive statistics of the seminiferous tubule diameter per group and surgery, and results of the Kruskal-Wallis test.

\begin{tabular}{|c|c|c|c|c|c|c|}
\hline \multirow[t]{2}{*}{ Operation } & \multirow[t]{2}{*}{ Group } & \multicolumn{3}{|c|}{ Diameter $(\mu \mathrm{m})$} & \multicolumn{2}{|c|}{$\begin{array}{l}\text { Results of the } \\
\text { Kruskal-Wallis } \\
\text { test }\end{array}$} \\
\hline & & Median & Avg. & $\begin{array}{c}\text { SD- } \\
\text { Deviation }\end{array}$ & $\begin{array}{c}\text { Mid } \\
\text { Points }\end{array}$ & $\begin{array}{c}\text { P- } \\
\text { value }\end{array}$ \\
\hline \multirow{3}{*}{ First } & Control & 303.00 & 293.93 & 46.93 & 651.61 & \multirow{3}{*}{0.000} \\
\hline & G1 & 238.13 & 235.87 & 54.54 & 366.93 & \\
\hline & G2 & 230.13 & 233.47 & 38.27 & 332.97 & \\
\hline \multirow{3}{*}{ Second } & Control & 306.75 & 299.57 & 42.33 & 480.73 & \multirow{3}{*}{0.012} \\
\hline & G1 & 299.53 & 285.54 & 57.23 & 417.83 & \\
\hline & G2 & 302.38 & 297.19 & 41.55 & 452.95 & \\
\hline
\end{tabular}

With respect to thickness, a statistically significant difference between the groups in both surgeries was observed: the Control group had higher values than G1 and G2, which were similar between themselves (Table 2).

TABLE 2 - Descriptive statistics of the epithelium thickness per group and surgery and the result of the Kruskal-Wallis test.

\begin{tabular}{|c|c|c|c|c|c|c|}
\hline \multirow[t]{2}{*}{ Operation } & \multirow[t]{2}{*}{ Group } & \multicolumn{3}{|c|}{ Epithelium Thickness ( $\mu \mathrm{m})$} & \multicolumn{2}{|c|}{$\begin{array}{c}\text { Results of the } \\
\text { Kruskal-Wallis } \\
\text { test }\end{array}$} \\
\hline & & Median & Avg. & $\begin{array}{c}\text { SD- } \\
\text { Deviation }\end{array}$ & $\begin{array}{c}\text { Mid } \\
\text { Points }\end{array}$ & P-value \\
\hline \multirow{3}{*}{ First } & Control & 76.65 & 73.34 & 18.62 & 640.61 & \multirow{3}{*}{0.000} \\
\hline & G1 & 41.40 & 46.87 & 23.23 & 341.91 & \\
\hline & G2 & 48.20 & 49.74 & 17.17 & 368.98 & \\
\hline \multirow{3}{*}{ Second } & Control & 81.00 & 79.12 & 17.38 & 485.11 & \multirow{3}{*}{0.013} \\
\hline & G1 & 78.70 & 71.36 & 25.65 & 424.38 & \\
\hline & G2 & 78.10 & 77.15 & 14.35 & 442.01 & \\
\hline
\end{tabular}


Comparing operation timing in each of the groups, significant statistical difference was found for diameter in groups G1 and G2, while in the second surgery the diameter values were higher. And a statistically significant difference was found for thickness in all groups, while in the second surgery the thickness values were higher (Tables 3 and 4).

TABLE 3 - Descriptive statistics of diameter per group and surgery and results of the Mann-Whitney test.

\begin{tabular}{|c|c|c|c|c|c|c|}
\hline \multirow[t]{2}{*}{ Groups } & \multirow[t]{2}{*}{ Operation } & \multicolumn{3}{|c|}{ Diameter $(\mu \mathrm{m})$} & \multicolumn{2}{|c|}{$\begin{array}{c}\text { Results of the } \\
\text { Mann-Whitney } \\
\text { test }\end{array}$} \\
\hline & & Median & Avg. & $\begin{array}{c}\text { SD. } \\
\text { Deviation }\end{array}$ & $\begin{array}{c}\text { Mid } \\
\text { Points }\end{array}$ & $\begin{array}{c}P \text { - } \\
\text { value }\end{array}$ \\
\hline \multirow{2}{*}{ Control } & First & 303.00 & 293.93 & 46.93 & 288.13 & \multirow{2}{*}{0.081} \\
\hline & Second & 306.75 & 299.57 & 42.33 & 312.87 & \\
\hline \multirow{2}{*}{ G1 } & First & 238.13 & 235.87 & 54.54 & 230.43 & \multirow{2}{*}{0.00} \\
\hline & Second & 299.53 & 285.54 & 57.23 & 370.57 & \\
\hline \multirow{2}{*}{ G2 } & First & 230.13 & 233.47 & 38.27 & 186.16 & \multirow{2}{*}{0.000} \\
\hline & Second & 302.38 & 297.19 & 41.55 & 414.85 & \\
\hline
\end{tabular}

TABLE 4 - Descriptive statistics of thickness per group and surgery and results of the Mann-Whitney test.

\begin{tabular}{|c|c|c|c|c|c|c|}
\hline \multirow[t]{2}{*}{ Groups } & \multirow[t]{2}{*}{ Operation } & \multicolumn{3}{|c|}{ Thickness $(\mu \mathrm{m})$} & \multicolumn{2}{|c|}{$\begin{array}{c}\text { Results of the } \\
\text { Mann-Whitney } \\
\text { test }\end{array}$} \\
\hline & & Median & Avg. & $\begin{array}{c}\text { SD. } \\
\text { Deviation }\end{array}$ & $\begin{array}{c}\text { Mid } \\
\text { Points }\end{array}$ & $\begin{array}{c}P \text { - } \\
\text { value }\end{array}$ \\
\hline \multirow[t]{2}{*}{ Control } & First & 76.65 & 73.34 & 18.62 & 273.22 & 0.000 \\
\hline & Second & 81.00 & 79.12 & 17.38 & 327.78 & \\
\hline \multirow[t]{2}{*}{ G1 } & First & 41.40 & 46.87 & 23.23 & 221.36 & 0.000 \\
\hline & Second & 78.70 & 71.36 & 25.65 & 379.64 & \\
\hline \multirow[t]{2}{*}{ G2 } & First & 48.20 & 49.74 & 17.17 & 185.27 & 0.000 \\
\hline & Second & 78.10 & 77.15 & 14.35 & 415.73 & \\
\hline
\end{tabular}

\section{Discussion}

The testicle of mammals is an organ susceptible to toxic environmental or therapeutic agents that compromise spermatogenesis. The analysis of seminiferous tubules (morphological and morphometric parameters) is a simple strategy to assess changes in this process ${ }^{19}$.

According to Russell et $a .^{20}$, the spermatogenic process can be reduced by disrupting the pattern of stem cells division, of degeneration and phagocytosis of germ cells, delay in spermatogenesis and desquamation of germ cells, which may occur separately or in association in testicular parenchyma by hormonal deprivation or resulted from the toxic effects of chemical substances. In this experiment, qualitative histopathological findings of testicular parenchyma corroborate the quantitative data found.

Concerning the testicular Weight and Volume, rats in the Control group had the highest values, with no difference between G1 and G2. This suggests the hormone may affect, in a negative way, the size and weight of testicles and, consequently, the production or sperm. In this study, the dose was not decisive.

The measurement of the diameter tubular is an approach classically used as indicator of spermatogenic activity in investigations involving testicular function. The thickness of the seminiferous epithelium is also an effective feature for assessment of sperm production, since it follows the variations of the seminiferous epithelium cycle and of myoid cells ${ }^{21}$.

In this study, comparing the groups, it was observed that in the first surgery the seminiferous tubules Diameter was higher in the Control group, in relation to G1 and G2, and G1 and G2 were similar between themselves. This evidences that the groups treated with hormone had significant changes in their testicles, presenting averages below the Control group, but the hormone dose did not cause a statistical difference between G1 and G2 in this parameter.

In the second operation, the values of the Control group were higher than those of G1, and G2 did not present difference from the Control or from G1.

In relation to the Thickness of the seminiferous epithelium, both in the first and the second operation the values of the Control group were higher than G1 and G2, which are similar among themselves. This suggests again that there was a detrimental effect of the hormone, but that the dose did not influence these results, either.

Within each group, with respect to the time the surgery was performed, a statistically significant difference was found in groups G1 and G2, in which in the second operation both Diameter and Thickness values were higher, perhaps suggesting that there was a recovery of these parameters in the second surgery, which was performed 30 days after the hormone applications were suspended, 45 days after the beginning of the work. That can be justified by the duration of the cycle of the seminiferous epithelium, which is 40 to 60 days in rats, considering a new cycle started at the time of the second operation ${ }^{22}$.

The qualitative changes observed in the testicles histology of some animals in Groups 1 and 2, such as atrophy of the seminiferous tubules with degeneration and decrease in the number of germ cells (apoptosis), loss of the architecture of the epithelium with desquamation of germ cells in the lumen, 
abnormal presence of multinucleated giant cells in the epithelium and vacuolization of Sertoli cells, are also described in other studies involving drug effects in the testicles of rats ${ }^{14}$. Probably caused by the effect of hormonal withdrawal, with the low dose of intratesticular testosterone as the main cause.

These changes were observed in the majority of rats in the first surgery, both in Group 1 and 2, and in a few rats in the second surgery, in Group 1. Once again, there is a suggestion of recovery, at least partially, of the normal testicular histology with the passing of time, without exposure to the hormone, as happened in the second surgery.

It has already been observed that both gonadotropins and testosterone play an essential role in preventing apoptosis in testicular cells. As the fluctuations in the gonadotropins levels are negligible, the drop in the intratesticular testosterone rates seems to be the main responsible for the occurrence of cell death both in the form of necrosis and apoptosis in cryptic testicles ${ }^{16}$.

The formation of multinucleated giant cells is observed as being one of the typical features in the seminiferous epithelium of cryptic testicles, being responsible for the removal of damaged cells. The occurrence of these cells is a non-specific response against induced stress as a result of several conditions that disrupt spermatogenesis, such as increased local temperature, oxidative stress and drop in the intratesticular levels of testosterone ${ }^{16}$.

The aim of the current treatment of cryptorchidism, including orchidopexy and hormonal treatment, is to improve the potential of fertility by improving the maturation and the number of germ cells in pre-pubescent boys. Treatment timing has been based on the knowledge that delay and defect in the pre-pubertal maturation of germ cells is associated with a reduction in the number of germ cells in cryptorchidism ${ }^{23}$. Pre-pubertal treatment with hormones could, theoretically, achieve a normal maturation and proliferation of germ cells by increasing the total number of these cells and improving the fertility rates ${ }^{24}$.

Hormonal therapy with hCG with or without $\mathrm{GnRH}$ analogues is used in some centers to induce the descent of the testicles, previously to surgical treatment. But there are studies that suggest an additional indication for hormone therapy, using GnRH analogues subsequently to orchidopexy, in order to stimulate the maturation and proliferation of germ cells and increase the fertility rates, with positive results ${ }^{1,7-10,24}$.

However, adverse effects of the hCG on testicular histology have been studied and demonstrated in many other clinical and experimental studies, some evidencing little benefit in the hormonal treatment of cryptorchidism and even deleterious effects $\mathrm{s}^{3,11-13,17,18,25,26}$.
The evaluation of the safety of hormonal treatment is compromised, as the studies differ considerably as to the methodology used. They differ in the type and dose of hormone used, in addition to the duration of treatment and the time for histological evaluation of testicles after hormonal therapy (acute or chronic). Further research, both clinical and experimental, are required to provide grounds for the use of hormonal therapy in the treatment of cryptorchidism, aiming at more reliable and satisfactory results, mainly concerning fertility in adult life.

\section{Conclusions}

Human chorionic gonadotropin is gonadotoxic in rats. This effect was temporary and can affect reproductive potential. The total recovery of testicular damage in the studied range could not be proved, and the effects were not dose-dependent.

\section{References}

1. Karaman IM, Kaya C, Ozturk M, Pirincci N, Yimazgumrukcu G, Tuken M. The effects of human chorionic gonadotropin on normal testicular tissue of rats: dose-dependence and reversibility. BJU Int. 2006;97:1116-8.

2. Hjertkvist M, Lackgren G, Ploen L, Bergh A. Does HCG treatment induce inflamation-like changes in undescend testes in boys? J Pediatr Surg. 1993;28(2):254-8.

3. Dunkel L, Taskinen S, Hovatta O, Tilly JL, Wikstrom S. Germ cell apoptosis after treatment of cryptorchidism with human chorionic gonadotropin is associated with impaired reproductive function in the adult. J Clin Invest. 1997; 100(9):2341-6.

4. Thorsson AV, Christiansen P, Ritzén M. Efficacy and safety of hormonal treatment of cryptorchidism: current state of the art. Acta Paediatr. 2007;96:628-30

5. Mathers MJ, Sperling H, Rübben H, Roth S. The undescended testis: Diagnosis, treatment and long-term consequences. Dtsch Arztebl Int. 2009;106(33):527-32.

6. Miller OF, Stock JA, Cilento BG, McAleer IM, Kaplan GW Prospective evaluation of human chorionic gonadotropin in the differentiation os undescendent testes from retractile testes. J Urol. 2003;169:2328-31.

7. Hadziselimovic F. Hormonal treatment of undescended testis. J Pediatr Endocrinol. 1987;2:1-5.

8. Zivkovic D, Bica DG, Hadziselimovic F. Effects of hormonal treatment on the contralateral descended testis in unilateral cryptorquidism. J Pediatr Urol. 2006;2:468-72.

9. Schwentner C, Oswald J, Kreczy A, Lunadek A, Bartsch G, Deibl M, Radmayr C. Neoadjuvant gonadotropin-releasing hormone therapy before surgery may improve the fertility index in undescended testes: a prospective randomized trial. J Urol. 2005;173:974-7.

10. Jallouli M, Rebai T, Abid N, Bendhaou M, Kassis M, Mhiri R. Neoadjuvant gonadotropin-releasing hormone therapy before surgery end effect on fertility index in unilateral undescend testes: a prospective randomized trial. J Pediatr Urol. 2009;73:1251-4.

11. Cortes D, Thorup J, Visfeldt J. Hormonal treatment may harm the germ cells in 1 to 3 year-old boys with cryptorchidism. J Urol. 2000;163:1290-2.

12. Chandrasekharam VVSS, Srinivas M, Das SN, Jha P, Bajpai M, 
Chaki SP, Misro MM. Prepubertal human chorionic gonadotropin injection affects pospubertal germ cell maturation and androgen production in rat testis. Urology. 2003;62:571-4.

13. Léon MD, Chiauzzi VA, Calvo JC, Charreau EH, Chemes HE. Acute hCG administration induces seminiferous tubule damage in the adult rat. Acta Physiol Pharmacol Lationoam. 1987;37(2):277-88.

14. Urban JA. Tamoxifen induced multinucleated cells (symplasts) and distortion of seminiferous tubules in rat testis. Asian J Androl. 2003;5:217-20.

15. Heiskanen P, Billig H, Toppari J, Kaleva M, Arsalo A, Rapola J, Dunkel L. Apoptotic cell death in the normal and cryptorchid human testis: the effect of human chorionic gonadotropin on testicular cell survival. Pediatr Res. 1996;40:351-6.

16. Chaki SP, Misro MM, Ghosh D, Gautam DK, Srinivas M. Apoptosis and cell removal in the cryptorchid rat testis. Apostosis. 2005; 10:395-405.

17. Udagawa K, Takeda M, Hosaka M, Kubota Y, Ogawa T. Recovery of spermatogenesis by high dose gonadotropin-releasing hormone analogue treatment in rat cryptorchid testis after orchiopexy. J Urol. 2002;168:1279-83.

18. Bergh A, Söder O. Studies of cryptorchidism in experimental animal models. Acta Paediatr. 2007;96:617-21.

19. Pannocchia MA, Borella MI, de Camargo ACM, Gilio JM, da Silva CA. Estratégia efetiva de fixação do testículo de ratos Wistar para avaliar os parâmetros morfológicos e morfométricos do epitélio seminífero. ConScientiae Saúde. 2008;7(2):227-33.

20. Russell LD, Sinhá- Hikim AP, Ettlin RA, Clegg ED. Evaluation of the testis: histological and histopathological. 1ed. Cache River Press, 1990.

21. Murta DVF, Gomes VCL, Martinez LCR. A organização celular dos testículos de mamíferos. Rev Cient Eletrônica Med Vet. 2013;11(20):1-12.

22. Costa DS, de Paula TAR. Espermatogênese em mamíferos. Scientia Vila Velha. 2003;4:53-72.

23. Huff DS, Fenig DM, Canning DA, Carr MC, Zderic SA, Snyder III HM. Abnormal germ cell development in cryptorquidism. Horm Res. 2001;55:11-7.
24. Hadziselimovic F, Herzog B. The importance of both an early orchidopexy and germ cell maturation for fertility. Lancet. 2001;358:1156-7.

25. Ritzén ME, Bergh A, Bjerknes R, Christiansen P, Cortes D, Haugen SE, Jörgensen N, Kollin C, Lindahl S, Läckgren G, Main KM, Nordenskjöld A, Radjpert-De Meyts E, Söder O, Taskinen S, Thorsson A, Thorup J, Toppari J, Virtanen H. Nordic consensus on treatment of undescend testes. Acta Paediatr. 2007;96:638-43.

26. Heiskanen P, Billig H, Toppari J, Kaleva M, Arsalo A, Rapola J, Dunkel L. Apoptotic cell death in the normal and cryptorchid human testis: the effect of human chorionic gonadotropin on testicular cell survival. Pediatr Res. 1996;40:351-6.

\section{Correspondence:}

Patricia Magnago Altoé

Avenida Hugo Musso, 810/1002

29101-280 Vila Velha - ES Brasil

Tel.: (55 27)3062-4791 / 98118-8008

patyeu@hotmail.com

Received: Dec 16, 2013

Review: Feb 19, 2014

Accepted: March 18, 2014

Conflict of interest: none

Financial source: none

${ }^{1}$ Research performed at Laboratory of Division of Surgery Principles, Surgery Department, School of Science, Santa Casa de Misericordia de Vitoria (EMESCAM), Vitoria-ES, Brazil. Part of Master degree thesis, Postgraduate Program in Applied Sciences in Surgery and Ophtalmology, Faculty of Medicine, Minas Gerais Federal University (UFMG). Tutor: Prof. Edson Samesima Tatsuo 